\title{
Life Can't Be Any Easier than This-Introduction of the Portable and Disposable V.A.C. Machines*
}

\author{
Muhammad Ali Hussain ${ }^{1}$, Lalindra Kuruppu ${ }^{2}$, Hardeep Jhattu ${ }^{1}$, Charlotte Ying ${ }^{1}$, \\ Simon Wharton ${ }^{2}$ \\ ${ }^{1}$ The Canberra Hospital, Canberra, Australia; ${ }^{2}$ Plastic Surgery Department, Russells Hall Hospital, Dudley, UK. \\ Email: dralihussain76@yahoo.com.au
}

Received December $16^{\text {th }}, 2011$; revised January $20^{\text {th }}, 2012$; accepted February $18^{\text {th }}, 2012$

\begin{abstract}
The application of controlled levels of negative pressure on to a wound has been shown to accelerate evacuation of dead cells, debris and fluid which eventually encourages wound healing in a verity of surgical wounds. Vacuum Assisted Closure (V.A.C.) therapy-KCI Medical Limited, the terminology by which this is widely known, became popular, especially among the plastic surgery professionals in America and soon gained recognition worldwide. It is now widely used in the UK to manage and assist healing in a wide variety of wounds. Although KCI's V.A.C. machines were the only ones on the market for a number of years, several wound management companies have now brought out their own machines and these are now known collectively as topical negative pressure therapy (TNPT). Traditional TNPT is often considered a relatively costly procedure. It is often used in patients with large wounds to facilitate dressing management and promote rapid cleaning and granulation. This may also allow them to be discharged to the community when they would otherwise remain inpatients, thereby saving bed days. Capital purchase of the machines is expensive and hospitals often rent or lease them on a short or long term basis. This can lead to difficulties in arranging the finances for discharge to the community. Subsequent dressing changes (recommended every 48 - 72 hrs) also incur high costs and involvement of the trained medical or nursing staff. As we all know; "Need is the mother of invention". The disposable TNPT machine (V.A.C. Via ${ }^{\mathrm{TM}}$, KCI Medical Ltd.) has been introduced to help to solve these problems. It is a single use machine, inclusive of a dressing and canister and available off the shelf. It is very cost effective, easy to use and is used for small to moderate sized wounds. Senior author is using this machine which excellent results and illustrated the use of this machine with pictures in this paper.
\end{abstract}

Keywords: Vacuum Assisted Closure; Portable and Disposable Machine; Plastic Surgery

\section{Introduction}

The method of using sub-atmospheric pressure for a prolonged period of time on a wound to promote debridement and wound healing was first documented by Fleischmann et al. in 1993 [1]. This topical negative pressure therapy (TNPT) dressing can be used in the treatment of many types of soft tissue wounds. This includes degloving injuries [2,3], donor sites, chronic radiation ulcers [4], infected sternotomy wounds [5,6] and various soft tissue injuries prior to surgical closure, grafting or reconstructtive surgery. The use of vacuum therapy has also been described in patients with compartment syndromes of the lower limb [7] and in patients with acute and chronic infections of various types [8] and in non-healing or chronic wounds like pressure sores has also been published $[9,10]$.

Smith et al. [11], in a retrospective review, described the use of vacuum pack technique as the treatment method

${ }^{*}$ Conflict of Interest: NA; Funding: NA. of choice for open abdomen management and temporary abdominal closure. TNPT has also been used following split thickness skin grafting in the treatment of burns and is claimed to be particularly useful for body sites with irregular or deep contours such as the perineum, hand or axilla $[12,13]$ as it increases graft bed contact by reduceing the chance of fluid accumulation under the graft and effectively splints the graft.

Microbiological studies showed that, compared with control values, tissue bacterial counts of vacuum-treated wounds decreased significantly after four days [14]. The optimum level of negative pressure for wound healing is thought to be around $125 \mathrm{mmHg}$ below ambient and a continuous pressure is proved to be the most effective for splinting or bolstering grafts in place.

\section{How the Portable, Disposable V.A.C. Machine (V.A.C. Via) Works}

Disposable V.A.C. Via ${ }^{\mathrm{TM}}$ System (also called vacuum 
therapy, vacuum assisted closure, vacuum sealing or topical negative pressure therapy) is a sophisticated and modern development of a standard surgical technique.

A portable and disposable V.A.C. therapy system provides simplicity, mobility, and convenience like never before. The technique used in setting up the dressing and V.A.C. Via ${ }^{\mathrm{TM}}$ is very simple. The wound is covered in all directions with an air tight seal and then connected to a vacuum in a light weight disposable machine via a tube through which all fluid and air is sucked out in to a container. The machine comes with foam and transparent adhesive dressings (Figure 1).

The entire wound area is covered with the foam and then a transparent adhesive membrane is firmly secured on the top of the wound area and to the healthy skin around the wound margin ensuring air seal. Then a hole is created in the film and a self adhesive drain is attached over the hole. The drain tube is then connected to the vacuum source, where the fluid and debris from the wound is drawn out through the foam into a reservoir for subsequent disposal.

\section{Clinical Experience with Disposable V.A.C. Machine}

We used the disposable V.A.C. Via ${ }^{\mathrm{TM}}$ in 52 yrs of age gentleman, who presented with a pretibial abscess on the right lower leg. He underwent debridement twice under general anaesthetic and following debridement, the resulting wound measured the size of $5 \mathrm{~cm}$ by $4 \mathrm{~cm}$ as shown in Figure 2.

The wound was covered with split skin graft and to secure the graft, staples were used as shown in Figure 3.

Mepitel was applied on the graft, and then covered with foam with the disposable V.A.C. $\mathrm{Via}^{\mathrm{TM}}$ as shown in Figure 4.

The patient was discharged home the same day and followed up in the dressing clinic one week later. V.A.C. dressing was removed and graft was 100\% taken. (Figures 5(a) and 5(b))

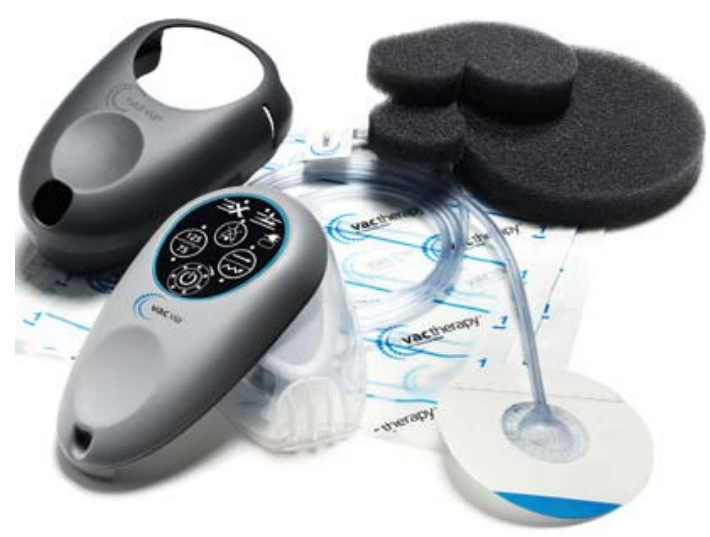

Figure 1. V.A.C. Via $^{\mathrm{TM}}$ unit as a whole.

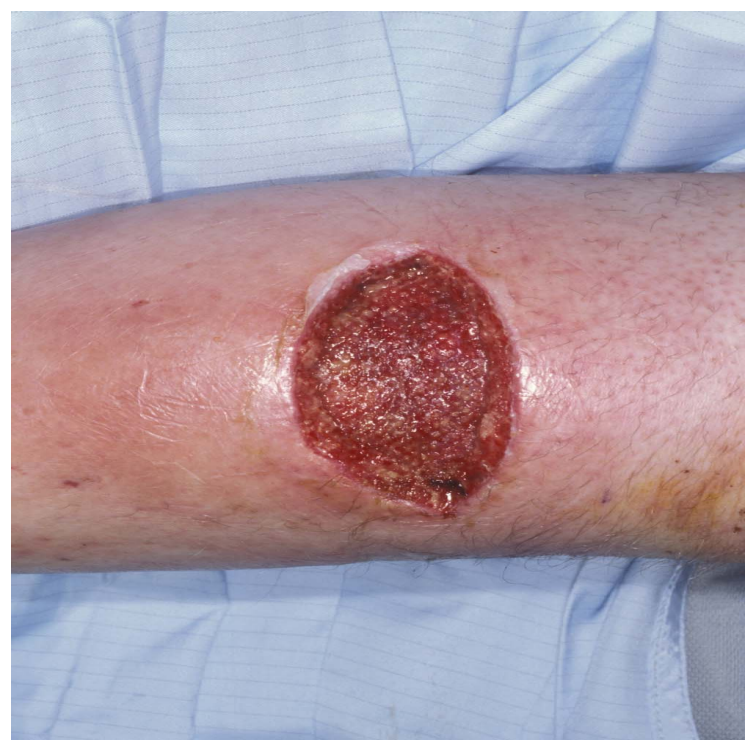

Figure 2. Wound right lower leg.

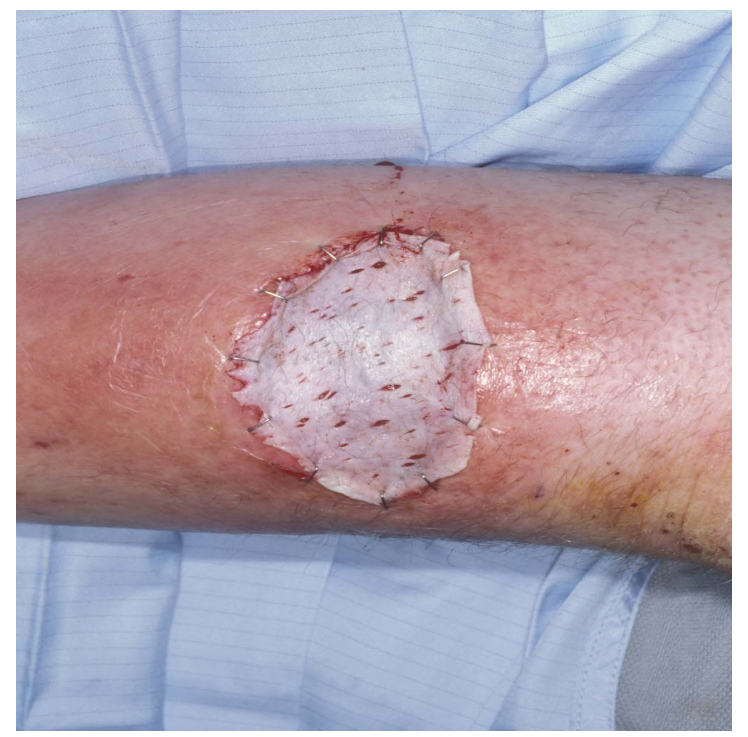

Figure 3. Split skin graft on the wound.

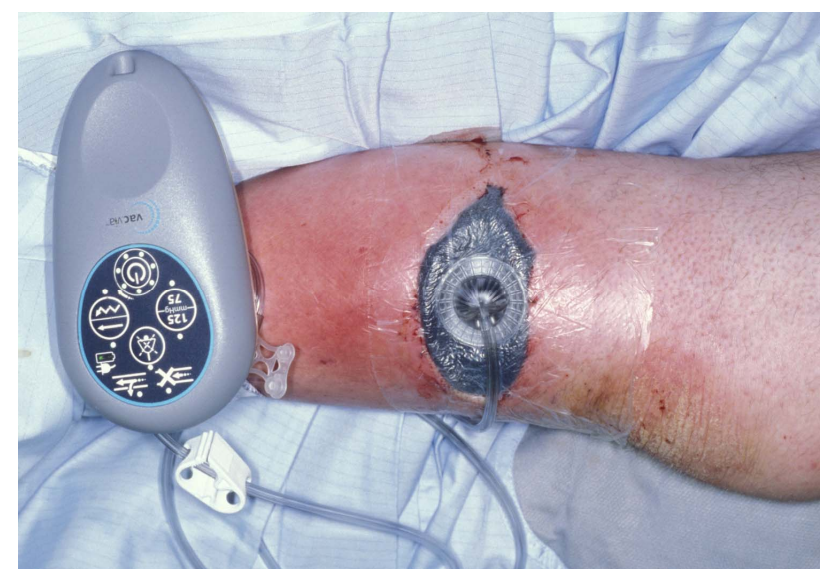

Figure 4. V.A.C. Via ${ }^{\mathrm{TM}}$ system applied on the lower leg wound. 


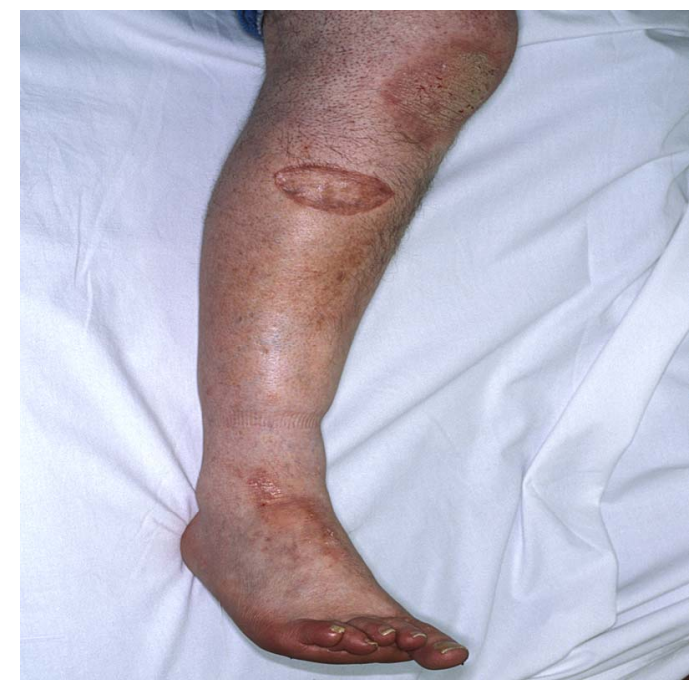

(a)

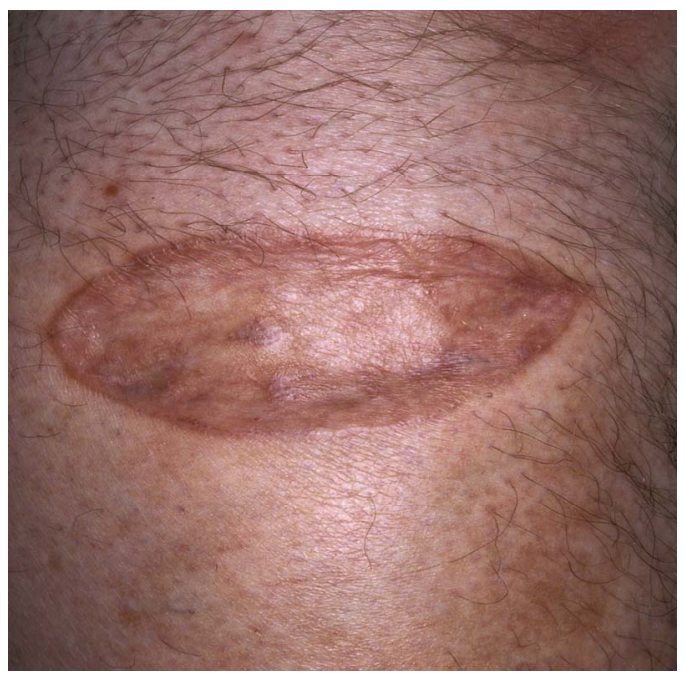

(b)

Figure 5. (a) and (b)—Post op pictures with taken grafts.

Patient didn't find it difficult to cope with the dressing and the machine as thorough post op instructions were given to the patient. This type of portable and disposable dressing has proved to be a very effective treatment modality for a variety of wounds because of its simplicity, mobility, ease and availability as whenever one is needed; all the equipment is present in a single box stored in theatre.

\section{Cost Effectiveness of the Disposable V.A.C. Machines}

The cost of the traditional TNPT therapy is not insignificant. In addition to the purchase cost $(£ 15,000)$ or hire charges (£26/day) of the machine itself, it is necessary to purchase disposable foam dressings and drainage tubes (small simplace granufoam dressing kit costs £23.40), canisters (£28.35) and adhesive drapes. Secondly, it is often necessary to keep the patient in the hospital until community V.A.C. is organized. Each bed in the hospital costs almost $£ 450$ per day.

With the introduction of the disposable V.A.C. machines (V.A.C. Via ${ }^{\mathrm{TM}}$ ), this cost has gone down remarkably. Discharge to the community is easy as there are no finances to be arranged. Subsequent dressings are done in the hospital dressing clinic. The machine works for a week and the whole pack (V.A.C. Via ${ }^{\mathrm{TM}}$ unit; charger; lanyard; pouch; medium granufoam dressing kit; 250ml canister and adhesive drapes) costs £260. This cost is less than the cost incurred in the use of the traditional machines. With the disposable V.A.C., the patient can be discharged home early therefore saving additional expenses.

\section{Statistical Analysis}

We divided the patients in 3 groups, who underwent similar procedures and compared costs in the use of traditional V.A.C. machines versus the V.A.C. Via ${ }^{\mathrm{TM}}$ unit, costs of hospital stay is also considered. All data is compiled into the following tables and a student t-test value is used to calculate a p-value.

Patients example group 1-Debridement of lower leg infected ulcer + graft

\begin{tabular}{cccccc}
\hline $\begin{array}{c}\text { Hospital } \\
\text { Stay } \\
£ 450 / \text { day }\end{array}$ & $\begin{array}{c}\text { V.A.C. } \\
\text { Machine } \\
(\text { price in } £)\end{array}$ & $\begin{array}{c}\text { Canister } \\
£ 28.35 \\
\text { each }\end{array}$ & $\begin{array}{c}\text { Kit } \\
£ 23.40 \\
\text { each }\end{array}$ & $\begin{array}{c}\text { Total } \\
\text { (price in } \\
£)\end{array}$ \\
\hline Traditional & $\begin{array}{c}16 \text { days }= \\
7200\end{array}$ & $\begin{array}{c}26 / \text { day }= \\
416\end{array}$ & $\begin{array}{c}\text { 6 changed }= \\
170.10\end{array}$ & $\begin{array}{c}6 \text { used }= \\
140.40\end{array}$ & 7926.50 \\
Disposable & $\begin{array}{c}\text { days }= \\
4050\end{array}$ & $\begin{array}{c}260 \text { each, } 2 \\
\text { used }=520\end{array}$ & None & None & 4570 \\
& & & & & \\
\hline
\end{tabular}

Patients example group 2-Debridement of heal ulcer + graft

\begin{tabular}{|c|c|c|c|c|c|}
\hline & $\begin{array}{l}\text { Hospital } \\
\text { Stay } \\
£ 450 / \text { day }\end{array}$ & $\begin{array}{c}\text { V.A.C. } \\
\text { Machine } \\
\text { (price in } £ \text { ) }\end{array}$ & $\begin{array}{c}\text { Canister } \\
£ 28.35 \\
\text { each }\end{array}$ & $\begin{array}{c}\text { Kit } \\
£ 23.40 \\
\text { each }\end{array}$ & $\begin{array}{c}\text { Total (price } \\
\text { in } £ \text { ) }\end{array}$ \\
\hline Traditional & $\begin{array}{c}10 \text { days }= \\
4500\end{array}$ & $\begin{array}{c}26 / \text { day }= \\
260\end{array}$ & $\begin{array}{c}3 \text { changed }= \\
85.05\end{array}$ & $\begin{array}{c}3 \text { used }= \\
70.20\end{array}$ & 4915.25 \\
\hline Disposable & $\begin{array}{c}6 \text { days }= \\
2700\end{array}$ & $\begin{array}{l}260 \text { each, } 1 \\
\text { used }=260\end{array}$ & None & None & 2960 \\
\hline
\end{tabular}

Patient example group 3-Elective skin lesion excisions + grafts

\begin{tabular}{cccccc}
\hline $\begin{array}{c}\text { Hospital } \\
\text { Stay } \\
£ 450 / \text { day }\end{array}$ & $\begin{array}{c}\text { V.A.C. } \\
\text { Machine } \\
\text { (price in } £ \text { ) }\end{array}$ & $\begin{array}{c}\text { Canister } \\
£ 28.35 \\
\text { each }\end{array}$ & $\begin{array}{c}\text { Kit } £ 23.40 \\
\text { each }\end{array}$ & $\begin{array}{c}\text { Total (price } \\
\text { in } £ \text { ) }\end{array}$ \\
\hline Traditional & $\begin{array}{c}6 \text { days }= \\
2700\end{array}$ & $\begin{array}{c}126 \\
1 \text { day }=\end{array}$ & $\begin{array}{c}1 \text { used }= \\
28.35\end{array}$ & $\begin{array}{c}1 \text { used }= \\
23.40\end{array}$ & 2877.75 \\
Disposable 1 day $=450$ & $\begin{array}{c}260 \text { each, } 1 \\
\text { used }=260\end{array}$ & None & None & 710 \\
\hline
\end{tabular}


Cumulative Data-Traditional vs. Disposable

\begin{tabular}{cccc}
\hline & $\begin{array}{c}\text { Patient group 1 } \\
(£)\end{array}$ & $\begin{array}{c}\text { Patient group 2 } \\
(£)\end{array}$ & $\begin{array}{c}\text { Patient group 3 } \\
(£)\end{array}$ \\
\hline $\begin{array}{c}\text { Traditional } \\
\text { V.A.C. }\end{array}$ & 7926.50 & 4915.25 & 2877.75 \\
$\begin{array}{c}\text { Disposable } \\
\text { V.A.C. }\end{array}$ & 4570.00 & 2960.00 & 710.00 \\
\hline
\end{tabular}

Using the above data and a student t-test, we conclude with a two-tailed p-value of 0.02 , which is considered to be statistically significant.

\section{Benefits of the Disposable and Portable V.A.C. Therapy System}

There are various benefits of a disposable and portable V.A.C. Via $^{\mathrm{TM}}$ system over current TNPT therapy products:

1) Potentially decreases in hospital stay due to quicker patient discharge process.

2) Uninterrupted V.A.C. Therapy at discharge.

3) Simple application requiring minimal staff training, V.A.C. $\mathrm{Via}^{\mathrm{TM}}$ is much easier to use than the traditional TNPT machines.

4) Reduced administrative coordination by eliminating the steps to activate and discontinue therapy.

5) Increased patient satisfaction with ability to conceal device and silent nature of therapy.

Increased patient compliance since therapy will not disturb patient's environment.

\section{REFERENCES}

[1] W. Fleischmann, W. Strecker, M. Bombelli and L. Kinzl, "Vacuum Sealing as Treatment of Soft Tissue Damage in Open Fractures,” Unfallchirurg, Vol. 96, No. 9, 1993, pp. 488-492.

[2] J. G. Meara, L. Guo, J. D. Smith, J. J. Pribaz, K. H. Breuing and D. P. Orgill, "Vacuum-Assisted Closure in the Treatment of Degloving Injuries," Annals of Plastic Surgery, Vol. 42, No. 6, 1999, pp. 589-594.

[3] A. J. DeFranzo, M. W. Marks, L. C. Argenta and D. G. Genecov, "Vacuum-Assisted Closure for the Treatment of Degloving Injuries," Plastic and Reconstructive Surgery, Vol. 104, No. 7, 1999, pp. 2145-2148. doi:10.1097/00006534-199912000-00031

[4] L. Kovacs, M. Kloppel, S. Geishauser, S. Schmiedl and E. Biemer, "Vacuum Sealing: A New and Promising Regimen in the Therapy of Radiation Ulcers," British Journal of Surgery, Vol. 85, No. 70, 1998, p. 26.

[5] A. T. Tang, S. K. Ohri and M. P. Haw, "Vacuum-Assisted Closure to Treat Deep Sternal Wound Infection Following Cardiac Surgery,” Journal of Wound Care, Vol. 9, No. 5, 2000, pp. 229-230.

[6] A. T. Tang, S. K. Ohri and M. P. Haw, "Novel Application of Vacuum Assisted Closure Technique to the Treatment of Sternotomy Wound Infection,” European Journal of Cardio-Thoracic Surgery, Vol. 17, No. 4, 2000, pp. 482-484. doi:10.1016/S1010-7940(00)00349-3

[7] W. Fleischmann, E. Lang and L. Kinzl, "Vacuum Assisted Wound Closure after Dermatofasciotomy of the Lower Extremity,” Unfallchirurg, Vol. 99, No. 4, 1996, pp. 283-287.

[8] W. Fleischmann, E. Lang and M. Russ, "Treatment of Infection by Vacuum Sealing,” Unfallchirurg, Vol. 100, No. 4, 1997, pp. 301-304. doi:10.1007/s001130050123

[9] A. K. Deva, C. Siu and W. J. Nettle, "Vacuum-Assisted Closure of a Sacral Pressure Sore," Journal of Wound Care, Vol. 6, No. 7, 1997, pp. 311-312.

[10] S. A. Baynham, P. Kohlman and H. P. Katner, "Treating Stage IV Pressure Ulcers with Negative Pressure Therapy: A Case Report," Ostomy Wound Manage, Vol. 45, No. 4, 1999, pp. 28-32, 34-35.

[11] L. A. Smith, D. E. Barker, C. W. Chase, L. B. Somberg, W. B. Brock and R. P. Burns, "Vacuum Pack Technique of Temporary Abdominal Closure: A Four-Year Experience," American Surgeon, Vol. 63, No. 12, 1997, pp. 1102-1108.

[12] A. M. Schneider, M. J. Morykwas and L. C. Argenta, “A New and Reliable Method of Securing Skin Grafts to the Difficult Recipient Bed," Plastic and Reconstructive Surgery, Vol. 102, No. 4, 1998, pp. 1195-1198. doi:10.1097/00006534-199809040-00045

[13] M. Pfau, H. O. Rennekampff and H. E. Schaller, "Skin Graft Fixation by Vacuum Assisted Topical Foam Dressing,” Journal of Burn Care \& Rehabilitation, Vol. 21, No. 1, 2000, p. 1.

[14] M. J. Morykwas, L. C. Argenta, E. I. Shelton-Brown and W. McGuirt, "Vacuum-Assisted Closure: A New Method for Wound Control and Treatment: Animal Studies and Basic Foundation,” Annals of Plastic Surgery, Vol. 38, No. 6, 1997, pp. 553-562. doi:10.1097/00000637-199706000-00001 